\title{
MANAJEMEN STRES DAN ANSIETAS UNTUK PENURUNAN TEKANAN DARAH
}

\author{
Ayu Pratiwi ${ }^{11}$, Yunike Edmaningsih ${ }^{2)}$ \\ 1)Program Studi IImu Keperawatan STIKes Yatsi, Tangerang, Banten, Indonesia \\ ${ }^{2}$ Sekolah Tinggi IImu Kesehatan Yatsi Tangerang STIKes Yatsi, Tangerang, Banten, Indonesia \\ Corresponding Author: Ayu Pratiwi \\ Email : ayu06pratiwi@gmail.com
}

Diterima 21 September 2020, Direvisi 20 November 2020, Disetujui 20 November 2020

\begin{abstract}
ABSTRAK
Kesehatan jiwa merupakan kondisi dimana seseorang dapat berkembang secara fisik, mental, spiritual serta sosial, serta mampu memberikan kontribusi bagi masyarakatnya. Individu tidak dapat bebas dari stres. Apabila stres tidak dikelola dengan baik dapat berlanjut menjadi ansietas dan masalah kesehatan jiwa lainnya. Data Riskesdas 2018 menunjukkan terjadi peningkatan jumlah penderita psikosis dari $1,7 \%$ menjadi $7 \%$ per mil, sedangkan penderita gangguan mental emosional meningkat dari 6 menjadi $9 \%$ per mil. Jumlah penderita depresi di provinsi Banten mencapai $8.7 \%$. Tingginya jumlah penderita gangguan jiwa dari waktu ke waktu membutuhkan tindakan promosi dan pencegahan gangguan jiwa. Pengabdian kepada masyarakat ini bertujuan agar warga masyarakat mampu mengenali tanda dan gejala stres dan ansietas serta dapat melakukan cara pengelolaannya. Kegiatan ini dilakukan melalui penyuluhan dan demonstrasi cara mengelola stres dan ansietas berupa teknik relaksasi napas dalam dan afirmasi positif, yang dihadiri 50 warga yang dihadiri oleh kader dan pengurus RT dan Kepala RW kp Gandu RT/RW 02/04 Desa Sindang Jaya kecamatan Sindang Jaya selaku mitra. Hasil kegiatan diukur dengan membandingkan nila pre-test dan post-test pengetahuan pasien sebelum dan sesudah dilakukan pemberian materi. Hasilnya, terdapat peningkatan pengetahuan warga sebelum dilakukan penyuluhan dengan persentase sebesar $60 \%$ dan setelah dilakukan penyuluhan persentase sebesar $100 \%$. terkait kesehatan jiwa, tanda gejala stres dan ansietas. Warga juga mampu melakukan tindakan yang diajarkan untuk mengelola stres dan ansietas. Kegiatan ini diharapkan dapat dilaksanakan secara berkelanjutan dengan bantuan para kader masyarakat.
\end{abstract}

Kata Kunci: ansietas; kesehatan jiwa; stres.

\begin{abstract}
Mental health is a condition in which a person can develop physically, mentally, spiritually and socially, and is able to contribute to his community. Individuals cannot be stress free. If stress is not managed properly it can lead to anxiety and other mental health problems. Riskesdas 2018 data shows an increase in the number of psychosis sufferers from $1.7 \%$ to $7 \%$ per mile, while people with mental emotional disorders have increased from 6 to $9 \%$ per mile. The number of people suffering from depression in Banten province reached $8.7 \%$. The high number of people with mental disorders from time to time requires promotional action and prevention of mental disorders. This community service aims to make community members able to recognize the signs and symptoms of stress and anxiety and be able to do how to manage them. This activity was carried out through counseling and demonstrations on how to manage stress and anxiety in the form of deep breath relaxation techniques and positive affirmations, which was attended by 50 residents attended by cadres and administrators of RT and Head of RW Kp Gandu RT / RW 02/04 Sindang Jaya Village, Sindang Jaya District as partners. The results of the activity were measured by comparing the pre-test and post-test values of the patient's knowledge before and after giving the material. As a result, there was an increase in the knowledge of the residents before extension with a percentage of $60 \%$ and after extension the percentage of $100 \%$. related to mental health, signs of stress and anxiety. Residents are also able to take actions that are taught to manage stress and anxiety. This activity is expected to be carried out in a sustainable manner with the help of community cadres.
\end{abstract} jiwa; stres.

Keyword: anxiety; mental health; stress

\section{PENDAHULUAN}

Kesehatan jiwa merupakan salah satu bagian integral dari kesehatan secara umum.
Kesehatan jiwa bukan hanya kondisi di mana seseorang terbebas dari gangguan jiwa, namun juga kondisi dimana individu memiliki 
kondisi emosi, psikologis dan sosial yang baik (Kemenkes, 2014). Kesehatan jiwa yang baik akan berpengaruh pada produktivitas seseorang. Tidak dipungkiri, dalam kehidupan sehari-hari individu tidak dapat terbebas dari stres atau tekanan. Stress yang dikelola dengan baik dapat berdampak pada pertumbuhan pribadi yang lebih baik dan matang. Namun stress yang tidak dikelola dengan baik, dapat berpotensi menimbulkan ansietas bahkan dapat menjadi permasalahan kesehatan jiwa yang lebih serius (Videbeck, 2011).

Estimasi prevalensi gangguan jiwa di Eropa pada tahun 2015 mencapai 110 juta, yang mana sama seperti $12 \%$ dari populasi. Masalah kejiwaan yang terbesar di Eropa yaitu depresi (44,3 juta) dan ansietas (37.3 juta). Sedangkan, penyebab stress di negara maju salah satunya seperti di Amerika antara lain karena masa depan negara (63\%), keuangan $62 \%)$, pekerjaan $(61 \%)$, politik $(57 \%)$, serta kekerasan dan kriminalitas (51\%). ${ }^{7}$ Indonesia merupakan negara berkembang yang juga masih belum terlepas dari masalah kesehatan jiwa. Prevalensi gangguan jiwa berat yaitu skizofrenia yang terdata pada tahun 2018 mencapai angka 7 permil. Angka ini meningkat dari lima tahun sebelumnya yaitu 1.7 per mil. Masalah kejiwaan lainnya seperti depresi menempati angka 6 per mil pada tahun 2018. Sedangkan prevalensi penderita gangguan mental emosional menempati posisi 9.8 per mil dari lima tahun sebelumnya yang menempati 6 per mil (Idaiani S, Riyadi I, 2018).

Kp Gandu RT/RW 02/04 Desa Sindang Jaya kecamatan Sindang Jaya penderita Depresi di provinsi Banten berdasarkan Riset Kesehatan Dasar 2018 berjumlah 8.7\%. Angka ini lebih tinggi dari rata-rata penderita depresi di Indonesia tahun 2018. Hal ini tidak jauh berbeda dengan penderita gangguan jiwa berat skizofrenia yang juga meningkat dari lima tahun sebelumnya. Melihat peningkatan angka penderita masalah kejiwaan, promosi yang berkaitan dengankesehatan jiwa sangat diperlukan. Promosi kesehatan jiwa merupakan upaya untuk meningkatkan kesehatan jiwa, memampukan individu ketika melalui situasi yang sulit dan memaksimalkan tugas perkembangan di usianya (Stuart, G. W., Keliat, B. A., \& Pasaribu J, 2016).

Berdasarkan penjelasan sebelumnya, kecemasan merupakan satusatunya faktor psikologis yang mempengaruhi hipertensi. Beberapa penelitian terdahulu, tekanan darah dari orang-orang yang menderita kecemasan dengan orang-orang yang tidak menderita kecemasan, didapatkan hasil tekanan darah yang lebih tinggi pada kelompok penderita kecemasan dari pada kelompok yang tidak cemas (Dewi N, Putri E, Kep M, J SK, Erwina $\mathrm{NI}$, Kep M, et al, 2014).

Kecemasan dapat diekspresikan melalui respons fisiologis, yaitu tubuh memberi respons dengan mengaktifkan sistem saraf otonom (simpatis maupun parasimpatis) (Thbihari., S, Mn Mawiong Andreecia, And Magh Senilo L, 2015). Sistem saraf simpatis akan mengaktifasi respons tubuh, sedangkan sistem saraf parasimpatis akan meminimalkan respons tubuh. Reaksi tubuh terhadap kecemasan adalah "fight or flight" (reaksi fisik tubuh terhadap ancaman dari luar), bila korteks otak menerima rangsang akan dikirim melalui saraf simpatis ke kelenjar adrenal yang akan melepaskan hormon epinefrin (adrenalin) yang merangsang jantung dan pembuluh darah sehingga efeknya adalah nafas menjadi lebih dalam, nadi meningkat, dan tekanan darah meningkat atau hipertensi.

Kesadaran masyarakat akan perlunya memelihara kesehatan jiwa menjadi hal yang perlu segera dilakukan. Upaya promosi kesehatan jiwa yang dilakukan pemerintah belum maksimal menjangkau masyarakat. Hal ini dibuktikan dengan belum ada nya kader kesehatan di Kp Gandu RT/RW 02/04 Desa Sindang Jaya kecamatan Sindang Jaya Pelayanan kesehatan jiwa masih berfokus pada kuratif seperti rujukan pasien yang mengalami masalah kesehatan jiwa. Apabila upaya promotif dan preventif kesehatan jiwa tidak gencar dilakukan maka angka masalah kejiwaan dan gangguan jiwa dapat meningkat.

Berdasarkan latar belakang di atas, dibuatlah pengabdian kepada masyarakat (PkM) yang bertujuan untuk memberikan pengetahuan terkait stress dan ansietas yang dapat dialami individu dalam kehidupan sehari hari, serta cara penanganan mandiri yang dapat dilakukan oleh warga.

\section{METODE}

Kegiatan PkM diawali dengan persiapan sebelum pelaksanaan yang terdiri dari melakukan perijinan kepada pihak kepala desa sekaligus Kp Gandu RT/RW 02/04 Desa Sindang Jaya kecamatan Sindang Jaya pada bulan Januari sampai dengan Oktober 2019. Setelah tim mendapatkan persetujuan ijin dari kepala desa, tim melakukan persamaan persepsi bersama anggota tim lainnya tentang topik penyuluhan dan metode penanganan stres dan ansietas. Selanjutnya tim melakukan sosialisasi kegiatan dan di sertai oleh pengurus RW dan kader masyarakat. Sasaran dari kegiatan ini adalah ibu-ibu dan bapak-bapak dengan rentang usia 30-60 tahun dengan kader kesehatan setempat. Dalam kegiatan ini 
melibatkan 1 orang dosen dan 3 orang mahasiswa dari STIKes Yatsi dengan tujuan agar ajang ini dapat dijadikan sebagai sarana bagi mahasiswa untuk belajar hidup bermasyarakat dan mengenali masalah kesehatan dimasyarakat serta upaya pencegahannya.

Kegiatan PkM dilakukan dengan metode penyuluhan dalam satu kali pertemuan. Sebelum penyuluhan dilaksanakan, peserta terlebih dahulu diberikan pre-test. Pre-test yang diberikan sejumlah lima pertanyaaan yang berisi pengertian kesehatan, pengertian kesehatan jiwa, gejala ansietas, gejala stres dan juga penanganan yang dilakukan dalam menangani stres. Kemudian peserta diberikan penyuluhan tentang stres dan ansietas yang meliputi: pengertian kesehatan jiwa, penyebab stres dan ansietas, serta penanganan kedua masalah tersebut. Setelah penyuluhan diberikan, tim mengajarkan metode untuk mengurangi stres dan ansietas. Adapun metode nya berupa teknik relaksasi napas dalam, afirmasi positif. Penyuluh pertama tama mendemonstrasikan kedua metode tersebut diatas lalu selanjutnya penyuluh meminta peserta mengulangi dan melakukan dua metode tersebut secara bersama-sama.

\section{HASIL DAN PEMBAHASAN Pengetahuan Warga Tentang Stres Dan Ansietas}

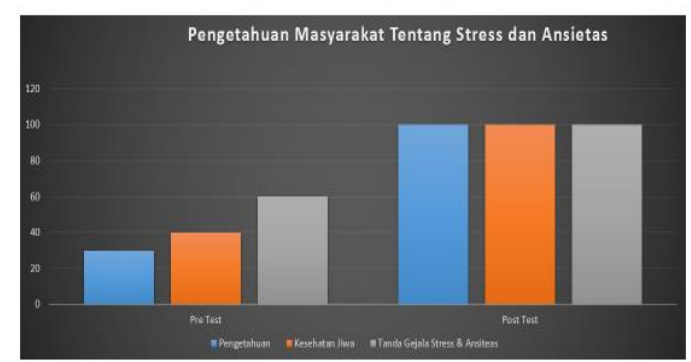

Gambar 1. Pengetahuan warga tentang stres dan ansietas sebelum dan sesudah diberikan penyuluhan

Berdasarkan Gambar 1 terdapat peningkatan pengetahuan warga yang signifikan setelah mendapatkan penyuluhan. Berdasarkan Gambar 1 terdapat peningkatan pengetahuan warga yang signifikan setelah mendapatkan penyuluhan dengan persentase sebelum penyuluhan $60 \%$ dan setelah penyuluhan $100 \%$ pengetahuan warga tentang stress dan ansietas. Hal ini sesuai dengan tujuan promosi kesehatan jiwa yaitu penyuluhan yang dilakukan untuk meningkatkan kemampuan masyarakat dalam menangani masalah (Stuart, G. W., Keliat, B. A., \& Pasaribu J, 2016). Hasil penelitian juga membuktikan bahwa penyuluhan kesehatan jiwa yang diberikan kepada masyarakat dapat meningkatkan dan memelihara kesehatan jiwa masyarakat. Pengetahuan yang meningkat tentang kesehatan jiwa diharapkan dapat membuat masyarakat lebih peduli terhadap pemeliharaan kesehatan jiwa khususnya dalam mengelola stres dan ansietas.

Warga Kp Gandu RT/RW 02/04 Desa Sindang Jaya kecamatan Sindang Jaya diberikan pertanyaan seputar pengertian kesehatan, kesehatan jiwa, serta tanda gejala stress dan ansietas. Selain itu, pengalaman warga untuk menangani stress dan ansietas juga digali. Berdasarkan jawaban warga, sebagian besar menyampaikan pemahaman yang belum mendalam terkait kesehatan jiwa. Disampaikan pula bahwa masalah yang terkait psikologis atau kejiwaan masih merupakan hal yang tabu untuk dibicarakan. Warga cenderung menghindari pembicaraan yang terkait masalah kejiwaan.

Tanda dan gejala yang dialami oleh warga terkait stres antara lain emosi menjadi mudah berubah, mudah tersinggung, sedih, enggan untuk kontak atau bertemu dengan orang lain. Berdasarkan penyebabnya, stress dapat dibedakan menjadi tiga tingkatan yaitu stress ringan, sedang dan berat. Individu yang mengalami stress ringan biasanya mengalami gejala yang tidak berdampak terhadap psikologis individu tersebut. Stress sedang terjadi lebih lama dibandingkan dengan stress ringan, dapat ditimbulkan dari beberapa jam hingga beberapa hari. Stress sedang dapat berasal dari pekerjaan sehari-hari. Stress berat merupakan level yang paling tinggi. Stress berat disebut juga stres kronis, penyebabnya dapat berasal dari hubungan keluarga yang tidak harmonis, kesulitan finansial, serta penyakit kronis (Stuart, G. W., Keliat, B. A., \& Pasaribu J, 2016)

Stres bisa dialami oleh setiap orang di dalam kehidupan sehari-hari dan penyebabnya sangat bervariasi. American Psychological Association (APA), (2019) melaporkan bahwa perempuan lebih cenderung memiliki tingkat stres yang meningkat dibandingkan pria, tidak hanya itu, perempuan juga diketahui lebih cenderung melaporkan gejala fisik dan gejala emosional saat stres (State THE, Our OF. STRESS IN AMERICA TM). Status menikah juga dilaporkan memiliki tingkat stres lebih tinggi dibandingkan individu yang tidak menikah. Penyebab stres dapat disebabkan oleh individu itu sendiri, keluarga, lingkungan atau bahkan dari pekerjaan. Pekerjaan merupakan salah satu hal yang dapat berkontribusi dalam meningkatkan stres bagi individu (Se A, Anto 
M, 2014). Pada kegiatan PkM ini, tim tidak mengidentifikasi secara khusus tingkat stres pada peserta berdasarkan jenis kelamin ataupun status pernikahan. Selanjutnya, tim juga tidak mengidentifikasi penyebab stress pada warga Kp Gandu RT/RW 02/04 Desa Sindang Jaya kecamatan Sindang Jaya, namun tim penyuluh memaparkan secara rinci hal-hal apa saja yang dapat menyebabkan seseorang mengalami stress.

Pada umumnya, ansietas ringanlah yang sering dialami oleh individu di dalam kehidupan sehari-hari. Dalam hal ini, ansietas ringan tergolong baik dialami oleh seseorang, karena dapat memberikan motivasi untuk menyelesaikan target yang perlu dicapai.

Tanda gejala yang dirasakan oleh warga ketika cemas yaitu jantung berdebar-debar, sakit kepala, sampai dengan terjadi peningkatan tekanan darah. Gejala yang disampaikan oleh warga ini didukung oleh teori tentang level ansietas, yang mana terdapat empat level ansietas dengan gejalanya yang berbeda-beda mulai dari ansietas ringan, sedang, berat sampai dengan panik. Ansietas ringan merupakan ansietas yang biasanya dialami saat terjadi ketegangan hidup seharihari. Ansietas ringan memberikan dampak yang baik bagi seseorang karena dapat memberikan motivasi dan mencegah individu mengalami suatu masalah. Ansietas sedang timbul dari ketegangan yang lebih berat lagi. Ansietas sedang membuat individu menajdi hanya berfokus pada hal yang sangat penting saja. Ansietas sedang membuat individu menjadi kurang perhatian terhadap apa yang ia lihat dan dengar. Terdapat gejala fisik yang menyertai pada tingkatan ini seperti banyak berkeringat, merasa gelisah, mondar-mandir serta wajah tampak pucat. Tingkatran lainnya yaitu ansietas berat. Individu yang mengalami ansietas berat mengalami penurunan pada kemampuan mempersepsikan sesuatu. Ketika berada pada ansietas berat, seseorang perlu bantuan untuk dapat fokus berpikir. Tahap yang paling tinggi dariansietas yaitu tahapan panik. Kondisi panik dikaitkan dengan rasa takut dan teror. Individu yang berada pada tahap ini tidak dapat melakukan hal apapun meskipun dengan diberikan arahan. Terjadi penurunan kemampuan dalam berhubungan dengan orang lain. Terdapat peningkatan aktivitas motorik seperti gemetar dan sebagainya. Tubuh pun memberikan respon terhadap kondisi panik ini, terjadi peningkatan tekanan darah dan tanda-tanda vital yang lainnya (Stuart, G. W., Keliat, B. A., \& Pasaribu $J, 2016)$. Berdasarkan penjelasan terkait level ansietas di atas, warga kemungkinan berada pada level ansietas ringan sampai sedang.
Namun pada pre test tidak diklasifikasikan level dari ansietas yang dialami oleh warga.

\section{Pengelolaan Stress dan Ansietas Warga}

Sebelum diberikan penyuluhan warga menyampaikan bahwa hal yang dilakukan ketika menghadapi stress dan ansietas biasanya yaitu berdoa, mengalihkan dengan bercerita dengan orang yang dipercaya, namun ada juga yang memendam di dalam hati. Warga menyampaikan bahwa belum pernah diadakan penyuluhan terkait cara-cara menangani stres atau ansietas sehingga mereka menangani stres dengan cara yang mereka mampu.

Pengelolaan stres dan ansietas warga yang diajarkan yaitu teknik relaksasi napas dalam dan afirmasi positif. Kedua cara ini dapat dilakukan secara mandiri oleh warga ketika sedang berada pada kondisi stres dan ansietas. Teknik relaksasi napas dalam efektif dalam menurunkan tingkat stres pada individu. Teknik relaksasi napas dalam juga diaplikasikan pada beberapa teknik manajemen stres Terdapat perubahan psikofisiologi pada tubuh dengan melakukan teknik relaksasi napas dalam. Teknik bernapas lambat mempengaruhi sistem saraf pusat dan otonom yang secara khusus berdampak terhadap jantung dan paru-paru (Creswell JW, 2014). Bila dikaitkan dengan tingkat stress dan ansietas, teknik relaksasi napas dalam dapat diterapkan pada stress dengan tingkatan ringan sampai sedang saja. Pada level ansietas berat dan stress berat, individu cenderung sulit memfokuskan pikiran dan mengendalikan diri sehingga akan sulit menerapkan tahapan relaksasi napas dalam. Setelah dijelaskan tentang car melakukan teknik relaksasi napas dalam, penyuluh meminta warga untuk mengulangi kembali tahapan teknik relaksasi napas dalam. Semua warga tampak mampu mempraktikkan teknik relaksasi napas dalam dengan baik sesuai dengan tahapan yang diajarkan.

Afirmasi positif merupakan cara terakhir yang diajarkan pada warga untuk menurunkan tingkat stress dalam kehidupan sehari-hari. Afirmasi positif merupakan cara untuk mengubah pikiran bawah sadar manusia dari pemikiran yang negatif menjadi pemikiran yang positif. Afirmasi positif yang dapat digunakan yaitu dengan mencari hal hal yang memotivasi diri. Misalnya "hari ini pekerjaan saya berjalan dengan baik", "saya berharga, saya dicintai banyak orang", "tubuh saya sehat, saya mampu melakukan banyak hal hari ini". Warga diminta untuk memikirkan kata-kata afirmasi yang sesuai dengan dirinya masing-masing.

Penelitian juga telah membuktikan bahwa 
didapatkan hubungan yang signifikan antara afirmasi positif dari nilai-nilai yang dianut oleh individu terhadap stres psikologis yang dihadapinya. Individu yang secara teratur melakukan afirmasi positif memiliki respon kortisol terhadap stres lebih rendah daripada individu yang tidak melakukan afirmasi positif. Afirmasi positif merupakan cara yang sangat efisien karena tidak menggunakan peralatan apapun dan hanya menggunakan diri sendiri. Dibutuhkan konsistensi warga dalam melatih untuk melakukan setiap manajemen stres yang diajarkan. Latihan manajemen stres dan ansietas yang dilakukan setiap hari membuat seseorang lebih terbiasa menggunakan teknik tersebut ketika sedang menghadapi kondisi stres (Creswell JW, 2014).

Manajemen stres merupakan salah satu perilaku positif yang bila terus menerus diulangi penggunaannya akan membentuk sebuah kebiasaan. Hal ini sejalan dengan teori perilaku yang menyebutkan bahwa perubahan perilaku dapat menjadi suatu perubahan yang stabil bila dilakukan terus menerus, dan dibutuhkan waktu sekitar minimal enam bulan untuk membuat suatu perilaku dilakukan dengan kesadaran sendiri oleh individu (Stuart, G. W., Keliat, B. A., \& Pasaribu J, 2016).

\section{SIMPULAN DAN SARAN}

Kegiatan pengabdian kepada masyarakat yang berbentuk penyuluhan manajemen stres dan ansietas warga di desa Sindang jaya Tangerang ini berhasil memberikan dampak berupa peningkatan pengetahuan warga terkait kesehatan jiwa, stres, ansietas serta cara penanganan stres dan ansietas oleh warga. Manajemen stres dan ansietas warga yang telah diajarkan berupa teknik relaksasi napas dalam, serta afirmasi positif. Beberapa teknik manajemen stres dan ansietas yang diajarkan ini tetap membutuhkan partisipasi setiap warga untuk konsisten melatih pelaksanaannya secara pribadi. Diharapkan warga dapat menangani stres dan ansietas sehari hari secara mandiri sehingga tercipta masyarakat yang sehat jiwa.

\section{UCAPAN TERIMAKASIH}

Terima kasih dan apresiasi kami sampaikan kepada Kepala Desa Sindang Jaya, perangkat RW dan RT, Ibu-lbu Kader Posyandu dan Posbindu, pihak,serta warga masyarakat Desa Sindang Jaya Tangerang yang telah berpartisipasi dalam pengabdian masyarakat berupa manajemen stres dan ansietas warga.

Terima kasih juga kami sampaikan pada pihak LPPM Stikes Yatsi yang telah memberikan kami kesempatan untuk melaksanakan kegiatan pengabdian masayakat yang merupakan salah satu upaya promosi kesehatan jiwa di masyarakat ini.

\section{DAFTAR RUJUKAN}

American Psychological Association. (2019). Gender and stres.

Idaiani, S., \& Riyadi, E. I. (2018). Sistem Kesehatan Jiwa di Indonesia: Tantangan untuk Memenuhi Kebutuhan. Jurnal Penelitian Dan Pengembangan Pelayanan Kesehatan, 2(2), 70-80. https://doi.org/10.22435/jpppk.v2i2.134

J.W., C. (2014). Psychiatric Mental Health Nursing. Pustaka Pelajar.

Putri, D. E., \& Erwina, I. (2012). Hubungan Dukungan Sosialdengan Tingkat Kecemasan Narapidanadi Lembaga Pemasyarakatan Klas II A Muaro Padang Tahun 2014. NERS Jurnal Keperawatan, 10(1). https://doi.org/10.25077/njk.10.2.118135.2014

Undang-Undang Republik Indonesia Nomor 18 Tahun 2014 Tentang Kesehatan Jiwa, (2014).

Seňová, A., \& Antošová, M. (2014). Work Stress as a Worldwide Problem in Present Time. Procedia - Social and Behavioral Sciences, $6, \quad 109$. https://doi.org/10.1016/j.sbspro.2013.12.4 63

Stuart, G. W., Keliat, B. A., \& P. J. (2016). Prinsip dan Praktik Keperawatan Kesehatan Jiwa Stuart. Elsevier Ltd.

Thbihari, S., Mn Mawiong Andreecia, A. M. S. L. (2015). Association Of Anxiety Disorder With Hypertension And Coronary Heart Disease:A Review. J Dent Med Sci., 4.

Videbeck, S. L. (2011). Psychiatric Mental Health Nursing. Lippincott Williams \& Wilkins. 